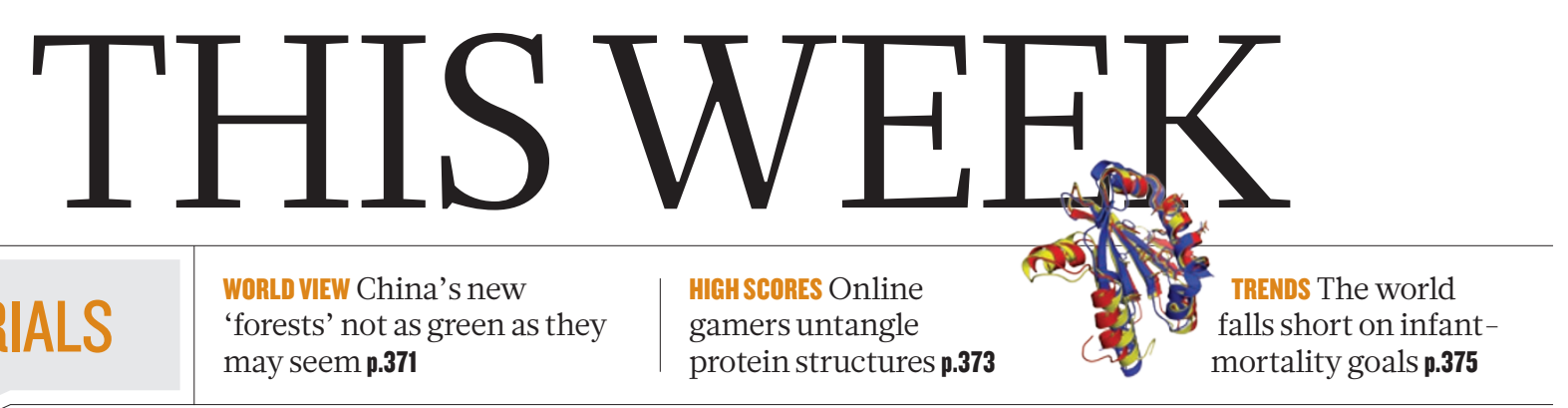

EDITORIALS 'forests' not as green as they may seem $\mathbf{p . 3 7 1}$ protein structures p.373

\title{
The wrong message on vaccines
}

\author{
Unfounded fears about vaccines are already reaching worrisome proportions. No public figure \\ should stoke them - as US presidential hopeful Michele Bachmann has done.
}

I n 2009 and 2010, fewer than half of all US states reported that the proportion of children aged five to six who were properly vaccinated against measles before they entered school had reached the desired $95 \%$. In parts of the country, the rate of refusal of mandatory childhood vaccinations for non-medical reasons stands at 25\%. And as-yet-unpublished data show that this rate in continuing to increase.

The results of vaccine refusal are already evident in Europe. France reported 4,937 cases of measles in the first three months of this year - nearly as many as in all of 2010. In total, 30 countries in the World Health Organization's European region reported a marked increase in measles cases early this year. At some point, the herd immunity that protects the unvaccinated and the immunosuppressed could be lost.

Against this backdrop, it is vital that public debates on vaccination stick to the facts - and that politicians who make science-supported decisions be applauded. Unfortunately, it was Michele Bachmann who received the applause at the Republican presidential candidates' debate earlier this month. The Minnesota congresswoman had attacked rival candidate Rick Perry for his failed attempt in 2007, as Texas governor, to mandate vaccination against human papilloma virus (HPV) for 11and 12-year-old schoolgirls, as recommended by the US Centers for Disease Control and Prevention (CDC) in Atlanta, Georgia.

Perhaps Perry did the right thing for the wrong reasons: he has close ties to pharmaceutical company Merck, a generous donor to his campaigns and the only maker of an HPV vaccine at the time of his attempt. But his goal was laudable: HPV is the most common sexually transmitted infection in the country and the major cause of cervical cancer, which kills 4,000 US women each year. The Food and Drug Administration has also approved the HPV jab for the prevention of vulvar and vaginal cancers, and of anal cancer in both males and females.

That did not stop Bachmann from making the astonishingly irresponsible claim, on national television, that the vaccine is a "potentially dangerous drug". She later suggested that it is linked to "mental retardation". Yet the CDC says that the vaccine is safe. Some 35 million doses have been delivered in the United States since its approval, but just $0.05 \%$ of recipients have reported side effects, mostly minor. Nor is there scientific support for the belief that presumably drives Bachmann's misstatements - that vaccinating prepubescent girls will somehow encourage them to become sexually active.

If Bachmann wants to do right by the millions of girls she claims to care about, she ought to retract her words and urge HPV vaccination. That might do more than anything else to combat an increasingly common parental mindset that takes for granted the past century of gains against infectious disease, and in so doing threatens to reverse them..

\section{Beyond the bomb}

\author{
Twenty years after the end of the cold war \\ scientists and the military still need each other.
}

W ith a science and technology budget that currently stands at about US $\$ 12$ billion per year, the US defence complex is the world's largest investor in military research. Much of the money has gone into developing weapons of unprecedented lethality, but a large fraction supports 'dual-use' research, whose products - from the Internet to the Global Positioning System — have enriched society as a whole. And the trove of military data has proved surprisingly useful to scientists studying environmental change (see page 388 ).

Military efforts are also helping to improve public health. Studies of traumatic brain injuries inflicted by bomb blasts (see page 390) could aid in the diagnosis and treatment of brain injuries in civilians. And the need to keep troops healthy has resulted in advances ranging from a partially effective vaccine against HIV to a mobile-phone-based reporting system for disease cases (see page 395).

Such programmes have been strengthened by JASON, an independent panel of high-level scientists whose advice is often brutally frank (see page 397). But the Pentagon can and should do much more to support dual-use science - by, for example, minimizing the bureaucracy and secrecy that still make it far too difficult for outsiders to gain access to military data.

Defence officials should also insist that their public-health research be meticulously transparent about goals and methods - this is crucial to overcoming mistrust in the developing world. At home, the Pentagon could enhance its credibility among academics by funding discussions on the ethical, legal and social implications of its research - for example, the development of robotic warfare (see page 399).

Most fundamentally, Congress and the Pentagon should continue their strong support for military science. This is not as axiomatic as it was when the United States was in a decades-long, high-stakes technological race with the Soviet Union. Much of today's military research, in the United States and elsewhere, consists of shorter-term problemsolving, such as how to deal with low-tech roadside explosives, or the development of virtual worlds for training troops or aiding their postinjury recovery (see page 406). As the mission becomes more diffuse, high-level support for military science may wane, especially as the Pentagon's overall funding comes under scrutiny (see page 386). Yet cutting and narrowing military research would be short-sighted, especially when the concept of national security is itself expanding, to include not just military strength, but public health, economic vigour, dealing with climate change, and all the other factors that make for a strong society. 